\title{
The Studies on Brdicka's Catalytic Hydrogen-Wave
}

\author{
I. The Reduction Waves of Cobalt Concerning to the Brdicka's \\ Catalytic Hydrogen-Wave
}

by

\author{
Hiroshi SunAHARA \\ (Goverment Industrial Research Institute, Nagoya)
}

(Received June 6, 1961)

\section{Introduction}

Since Brdicka discovered the catalytic double wave of hydrogen to be caused by a protein containing sulf hydryl or disulfide group in a solution of ammonia and ammonium chloride containing hexammine cobaltic chloride or cobaltous chloride, much has been studied on the mechanism. ${ }^{1-7)}$ The reactions which are responsible for the catalytic waves of proteins, cystine, cysteine and other mercaptans are not well understood, but cobalt and ammonia are seemed to be necessary constituents in the appearance of the catalytic wave.

The author considered the binding effects of active disulfide group in protein on cobalt and the effect of surface active character of protein on the cobalt reduction wave, and selected the following materials ; 1) Bovine Serum Albumin: the solution has both surface active character and disulfide group in it. 2) Gelatin: the solution has only surface active character and no disulfide group. 3) LEO (Polyoxyethylene laurylether) and Tween 80 (Polyoxyethylene sorbitan monooleate) as non-ionic surface active substance. These solutions have only surface active character and no disulfide group. Parameters studied with respect to their effect on the reduction wave of hexammine cobaltic chloride in ammoniacal ammonium chloride solution were the concentration of the proteins or surface active substances, electrocapillary curve at the constant concentration of these substances, and the evaluation of electron transfer coefficient times electron number, $\alpha$ n, of the first step of cobalt reduction wave in the presence of these substances. The influence of bovine serum albumin (BSA) on the reduction wave of hexammine cobaltic chloride in ammoniacal ammonium chloride solution were compared with the influences of other substances. The influence of BSA upon cobalt reduction wave was equal to the ones of the other surface active substances on the consideration of the surface active effect, but the character that is shifting the half-wave potential of the first or second step of cobalt reduction wave is different from gelatin, LEO and Tween 80. It is considered that this may depend upon active disulfide group in BSA.

In the studies on the mechanism of Brdicka's catalytic hydrogen wave, especially the effect of BSA being adsorbed on the surface of mercury drop, the influence on the cobalt reduction wave and the reaction between active disulfide group and cobalt were discussed.

On the reduction process of hexammine cobaltic chloride in ammoniacal ammonium chloride solution, the following equilibria are pertinent to the discussion and each step is called first or second step in each bracket. 


$$
\begin{aligned}
& {\left[\mathrm{Co}{ }^{\mathrm{II}}\left(\mathrm{NH}_{3}\right)_{6}\right]^{3+}+\mathrm{e}^{-} \longrightarrow\left[\mathrm{Co}{ }^{\pi}\left(\mathrm{NH}_{3}\right)_{6}{ }^{2+}\right. \text { and }} \\
& {\left[\mathrm{Co}^{\mathrm{II}}\left(\mathrm{NH}_{3}\right)_{6}\right]^{2+}+6 \mathrm{H}_{2} \mathrm{O} \longrightarrow} \\
& \quad\left[\mathrm{Co}^{\mathrm{I}}\left(\mathrm{H}_{2} \mathrm{O}\right)_{6}{ }^{2+}\right. \\
& \quad\left(\text { first step of cobalt, } \mathrm{E}_{\mathrm{t} / 2}=-0.26 \mathrm{~V} .\right) \\
& {\left[\mathrm{Co}^{\mathrm{II}}\left(\mathrm{H}_{2} \mathrm{O}\right)_{6}\right]^{2+}+2 \mathrm{e}^{-} \longrightarrow \mathrm{Co}(\mathrm{Hg})+6 \mathrm{H}_{2} \mathrm{O}} \\
& \quad\left(\text { second step of cobalt wave, } \mathrm{E}_{5 / 2}=-1.24 \mathrm{~V} .\right)
\end{aligned}
$$

Both the first step and the second step are irreversible processes. ${ }^{10-12)}$ The mechanism for the electron transfer of the step was explained by Vlcek ${ }^{1: 3}$ and Maki. ${ }^{14)}$

\section{Experimental}

A Shimadzu Pen Recording Polarograph Model PR-2 and Heyrovsky-Shikata type Shimadzu Polarograph Model SH-2 with the maximum sensitivity of galvanometer of $2.85 \times$ $10^{-9} \mathrm{~A} / \mathrm{mm} / \mathrm{m}$., were used for this study. Characteristics of capillary; $\mathrm{m}=1.98 \mathrm{mg}$. $\mathrm{sec}^{-1}, \tau$ $=4.12 \mathrm{sec}$. at $-1.0 \mathrm{~V} ., \mathrm{h}=54.7 \mathrm{~cm}$., in the solution of $0.1 M \mathrm{NH}_{3}$ and $0.1 M \mathrm{NH}_{4} \mathrm{Gl}$ containing $1 \mathrm{~m} M \mathrm{Co}\left(\mathrm{NH}_{3}\right)_{6} \mathrm{Cl}_{3}$. Pure nitrogen gas after passing through $0.1 M \mathrm{NH}_{3}$ and $0.1 M \mathrm{NH}_{4} \mathrm{Cl}$ solution was used to remove dissolved oxygen from the electrolytic solution before running polarograms. The potentials were measured against a saturated calomel electrode connected with a salt bridge having a low resistance $(230 \mathrm{Ohm})$. All polarographic waves were recorded at temperature of $25 \pm 0.2 \mathrm{C}$.

BSA purified by Armour and Company, Chicago, Ill., Gelatin purified for bacteriological research prepared by Difco Laboratory Inc., LEO (Polyoxyethylene laurylether) NikkoBL-10 prepared by Nikko Co., (given by Dr. H. Imai, Hiroshima University) and Tween 80 (Polyoxyethylene sorbitan monooleate) prepared by Nutrition Biochemical Corp., were used as surface active substances. A weighed amount of each substance was dissolved by small volume of redistilled water and diluted until a constant volume. Total amount was weighed. The percentage of these substances was calculated. The constituents of these stock solutions were $\mathrm{BSA}=0.49 \%$, Gelatin $=0.51 \%$, Tween $80=0.49 \%$, and $\mathrm{LEO}=0.49 \%$, respectively. The stock solutions of BSA and Gelatin were kept in refrigerator. All chemicals used were guaranteed reagent grade. The sample electrolyte was prepared by aliquot method from the stock solution, and the final volume was $25 \mathrm{ml}$. On the measurements of $\tau$ in order to get electrocapillary curve, 50 mercury drops were counted at each fixed potential by Shimadzu Polarograph Model SH-2.

\section{Results and Discussion}

The Influence of BSA, Gelatin and Tween 80, LEO on the Reduction Wave of Hexammine Cobaltic Chloride in Ammoniacal Ammonium Chloride Solution. Although various concentration in the range from $0.1 M$ to $1.0 M$ of ammonia have been used by various researchers to study on Brdicka's catalytic hydrogen wave, the author used the solution of $0.1 M \mathrm{NH}_{3}$ and $0.1 \mathrm{MNH}_{4} \mathrm{Cl}$ containing $1 \mathrm{~m} M$ hexammine cobaltic chloride as elcctrolytic back ground solution. The concentrations of proteins or surface active substances uscd were in the range from $5 \times 10^{-4} \%$ to $1 \times 10^{-1} \%$.

As the result of the influence of BSA or a surface active substance upon the first step of cobalt reduction wave, its half-wave potential shifted to more negative side with increasing concentration of BSA or a surface active substance, and this effect began appearing just after the maximum wave of the second step had been completely suppressed. The results were illustrated in Fig. 1. 

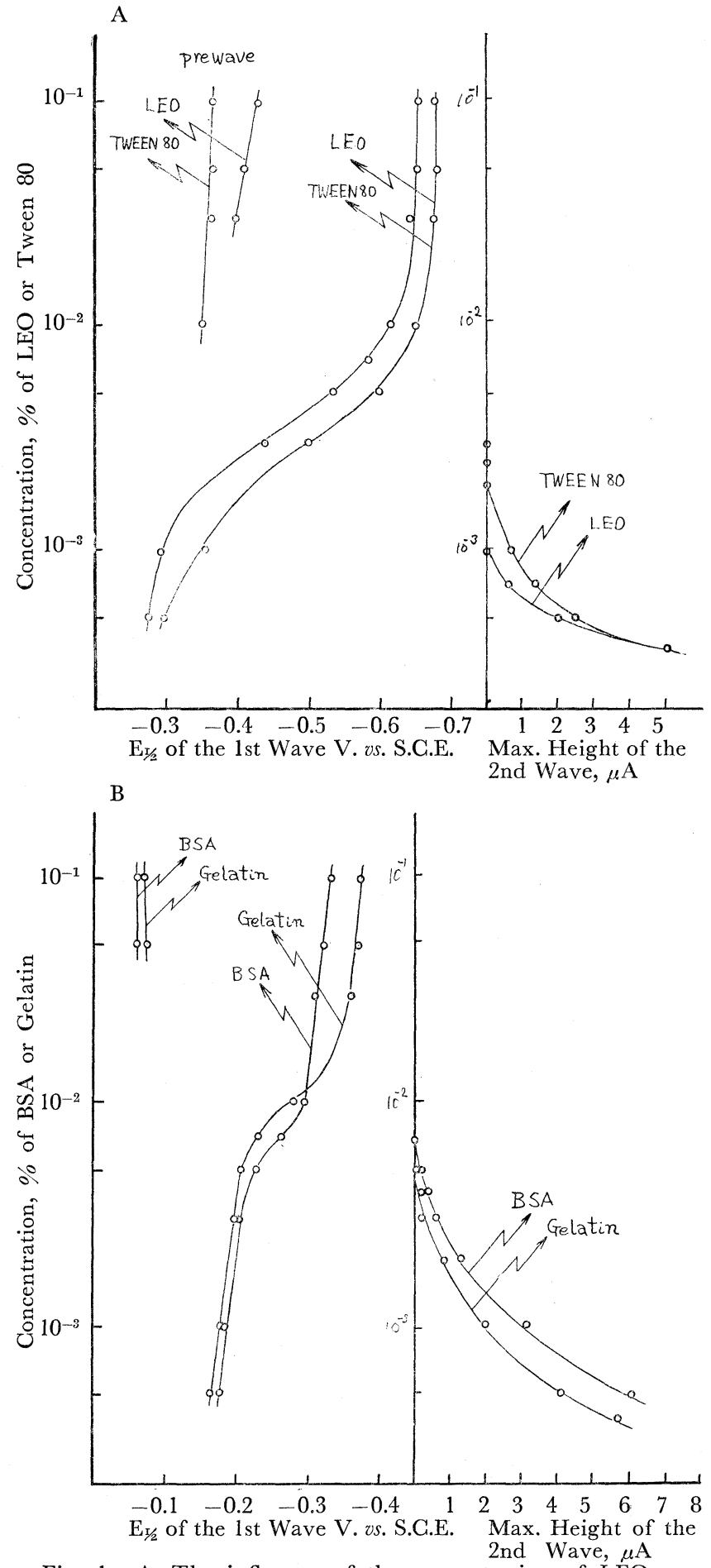

Fig. 1. A. The influence of the concentration of LEO or Tween 80 upon $\mathrm{E}_{1 / 2}$ of the 1st-wave and max. height of the 2 nd-wave of $\mathrm{Co}(\mathrm{III})$.

B. The influence of the concentration of BSA or Gelatin upon $E_{1 / 2}$ of the 1st-wave and max. height of the 2ndwave of Co (III).

The electrolytic solution : $\mathrm{Co}\left(\mathrm{NH}_{3}\right)_{6} \mathrm{Cl}_{3} 1.01 \mathrm{~m} M$ in $0.1 M$ $\mathrm{NH}_{3}$ and $0.1 M \mathrm{NH}_{4} \mathrm{Cl}$.
In the high concentration of BSA and a surface active substance, another wave appeared, i.e., in the case of Tween 80 , it is at $-0.35 \mathrm{~V}$. , in the case of BSA and Gelatin, it is at $-1.0 \mathrm{~V}$. The polarograms were illustrated in Fig. 2 and the behaviors of half-wave potentials against the concentration of surface active substances were in Fig. 1. As shown Fig. 2, the shifted reduction wave of the first step showed a well defined wave with increasing concentration of proteins and a surface active substance. The reduction wave of the first step seemed to be the reduction of $\mathrm{Co}\left(\mathrm{NH}_{3}\right)_{6}{ }^{8+}$ to a cobaltous complex.

To know the influence of BSA or a surface active substance upon the second step of cobalt, $\mathrm{Co}\left(\mathrm{H}_{2} \mathrm{O}\right)_{6}{ }^{2+} \rightarrow$ $\mathrm{Co}(\mathrm{Hg})$, the half-wave potential was measured after the maximum wave of the second step had been completely suppressed, and found that the half-wave potential shifted to more negative side with increasing concentration of LEO, Tween 80 or Gelatin, while the shifting to more positive side was recognized with increasing concentration of BSA. As shown in Fig. 3, at the concentration of $0.1 \%$ each substance, the half-wave potential of the second step were -1.35 $\mathrm{V}$. in the case of Tween 80 , $-1.31 \mathrm{~V}$. LEO, $-1.24 \mathrm{~V}$. 


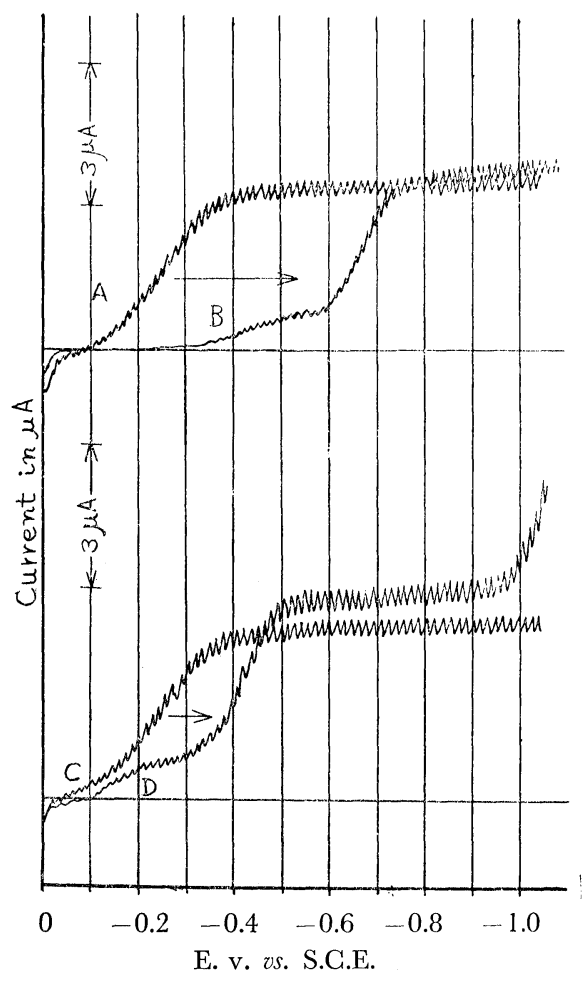

Fig. 2. The influence of LEO, BSA upon the 1st-wave of $\mathrm{Co}(\mathrm{III})$.

Polarograms :

$\mathrm{A}$ and $\mathrm{C}$ : the 1st-reduction wave of $\mathrm{Co}\left(\mathrm{NH}_{3}\right)_{6} \mathrm{Cl}_{3} 1.01 \mathrm{~m} M$ in 0.1 $M \mathrm{NH}_{3}+0.1 M \mathrm{NH}_{4} \mathrm{Cl}$.

$\mathrm{B} \quad$ : the 1 st-reduction wave of $\mathrm{Co}$ (III) contained $0.098 \%$ LEO.

D : the 1st-reduction wave of Co (III) contained $0.095 \% \mathrm{BSA}$.

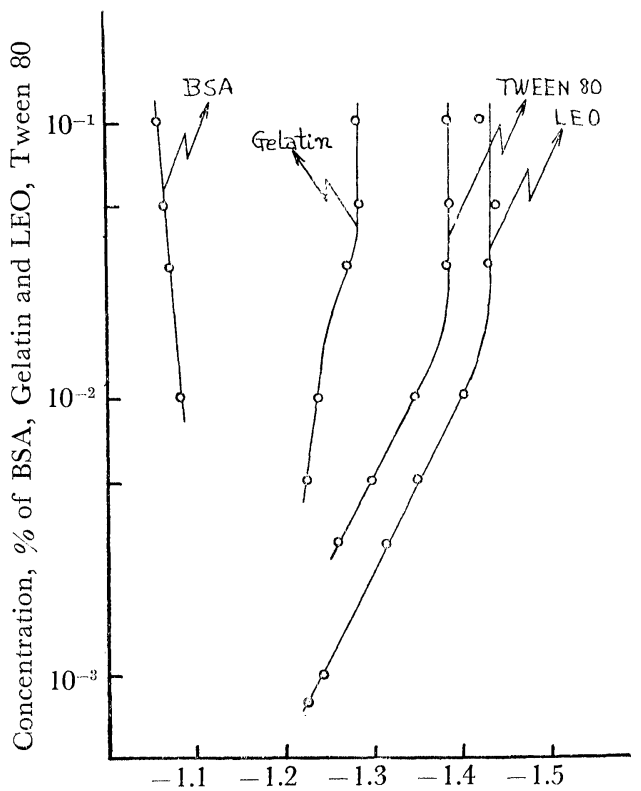

$\mathrm{E}_{\overline{2} / 2}$ of the 2nd-Wave of $\mathrm{Co}(\mathrm{III})$, V. vs. S.G.E.

Fig. 3. The influence of the concentration of BSA, Gelatin and LEO, Tween 80 upon $\mathrm{E}_{\mathrm{T} / 2}$ of the 2 nd-wave of Co(III).

The electrolytic solution : $\mathrm{Co}\left(\mathrm{NH}_{3}\right)_{6} \mathrm{Cl}$; $1.01 \mathrm{~m} M$ in $0.1 \mathrm{MNH}_{3}$ and $0.1 \mathrm{M} \mathrm{NH}_{4} \mathrm{Gl}$.

Gelatin, -1.077 V. BSA, respectively. These effects were considered as some influences of strong adsorption at mercury surface upon the reduction process. Gelatin and BSA showed the same behaviors as adsorption character against the first reduction wave of cobalt, but their behaviors for

the second reduction wave of cobalt showed an opposite effect from the point of shifting direction of half-wave potentials. The characteristic behavior of BSA was seemed being due to the fact that BSA has 17 disulfide groups per one molecule ${ }^{9)}$, and some of them naturally have possibility to coordinate with cobalt. As for the analogous instances it has been recognized in the case of cystine or octapolypeptide containing one disulfide group. ${ }^{8)}$

The effect of BSA, Gelatin or a surface active substance upon the first wave-hcight had hardly been recognized. On the contrary, the second wave-height decreased with some extents of increasing concentration of BSA or LEO, and again it became increasing with increasing concentration. The minimum concentration was found at $7 \times 10^{-3} \%$. With further increasing concentration, the wave-height decreased once more.

The Influence of BSA, Gelatin and Tween 80, LEO on the Electrocapillary Curve. In the solution of $0.1 M \mathrm{NH}_{3}$ and $0.1 M \mathrm{NH}_{4} \mathrm{Gl}$ containing hexammine cobaltic chloride, an adsorption character of BSA, Gelatin, LEO, or Tween 80 on the surface of mercury drop was studicd obtaining each electrocapillary curve. 


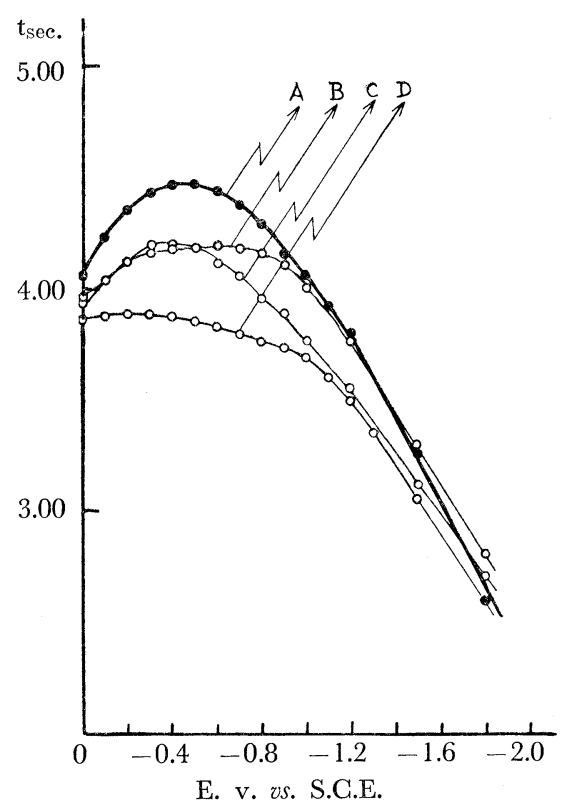

Fig. 4. Electrocapillary curves of the solution of ammoniacal ammonium chloride trivalent cobalt containing BSA, Gelatin and LEO.

A : $\mathrm{Co}\left(\mathrm{NH}_{3}\right)_{6} \mathrm{Cl}_{3}: 1.01 \mathrm{mM}_{3}: 0.1 \mathrm{M}$, $\mathrm{NH}_{4} \mathrm{Gl}: 0.1 \mathrm{M}$.

$\mathrm{B}$ : A contained $0.098 \%$ BSA

C : A contained $0.102 \%$ Gelatin

$\mathrm{D}$ : A contained $0.098 \%$ LEO
In Fig. 4 the electrocapillary curves in the cases of BSA and Gelatin of concentration of 0.1 $\%$ are shown. The lowering of surface tension due to the adsorption of proteins on the surface between mercury drop and the electrolyte was recognized with increasing concentration of BSA or Gelatin. In the cases of LEO and Tween 80, the electrocapillary curves showed the different character from the one of the proteins. Although a different character of adsorption between the above two groups can hardly be discussed in the connection of the mechanism of Brdicka's catalytic hydrogen wave, it is at least notable to consider the involvement of the significance of the adsorption.

The Evaluation of " $\alpha n$ " in the Reduction Process of Cobalt. In order to know the effect of BSA, Gelatin, LEO or Tween 80 on the electron transfer in the first reduction process, the value of $\alpha \mathrm{n}$ was estimated by using the equation of $\tan \theta=$ $2.2 \mathrm{RT} / \alpha \mathrm{nF}$ from the gradient of $\log i /\left(i_{d}-i\right)-E$, where $\alpha$ is electron transfer coefficient, $\mathrm{n}$ electron number in a reduction process, $\mathrm{R}$ gas constant (1.98 cal./deg. mol.), F Faraday constant 23062 (cal./V. equiv.). The value of $\alpha \mathrm{n}$ against the concentration of BSA, Gelatin, LEO or Tween 80 was plotted in Fig. 5. The value of $\alpha$ n has

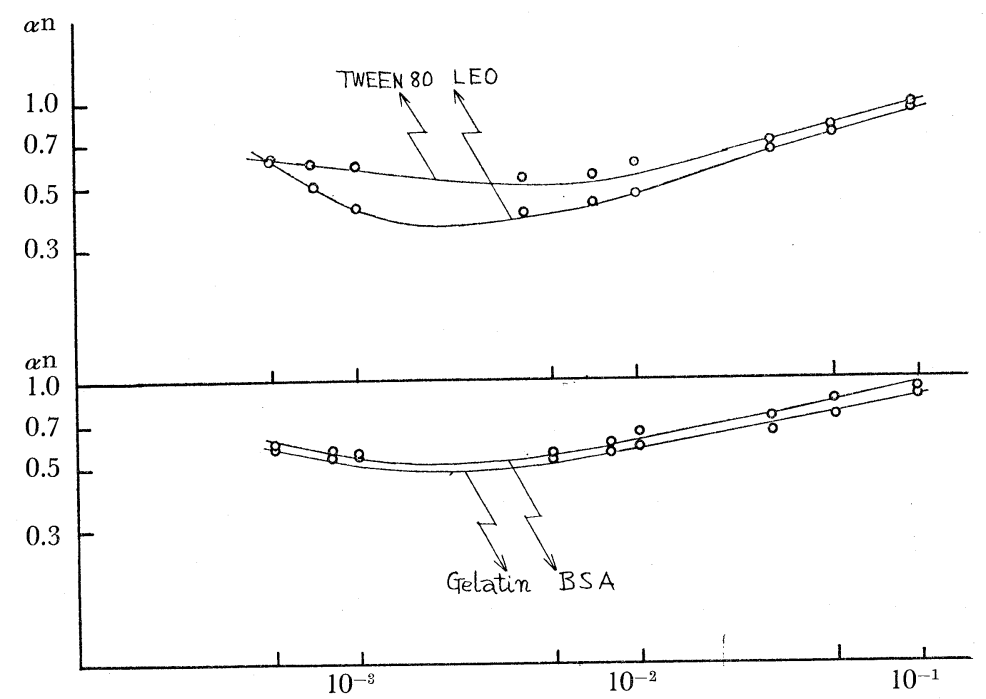

Concentration, $\%$ of BSA, Gelatin and Tween 80, LEO

Fig. 5. The Evaluation of $\alpha \mathrm{n}$ on the 1st-wave of $\mathrm{Co}(\mathrm{III})$ against various concentrations of BSA, Gelatin and LEO, Tween 80.

$\mathrm{Co}\left(\mathrm{NH}_{3}\right)_{6} \mathrm{Gl}_{3} ; 1.01 \mathrm{~m} M$ in $0.1 M \mathrm{NH}_{3}$ and $0.1 M: \mathrm{NH}_{4} \mathrm{Cl}$. 
minimum value at around $2 \times 10^{-:} \%$ of these substances, and intends to 1.0 as it approach to $0.1 \%$, corresponding to the fact that the first step of the wave generally a well defined pattern at such high concentration of the proteins or the surface active substances. It suggests that a strong adsorption on the surface of the mercury might furnish a reversible field for an irreversible process. The author is expecting further investigation about the problem.

\section{Acknowledgements}

The author wishes to express his gratitude to Professor M. Shinagawa, Department of Nuclear Technology, Faculty of Engineering, Osaka University, under whose direction the study was began when he had been the Professor of Faculty of Science, Hiroshima University, for his instructive advice and discussion, and to Dr. B. Jirgensons, Department of Biochemistry, University of Texas, M.D. Anderson Hospital and Tumor Institute, Houston Texs. U.SA., for given Bovine Serum Albumin. The participation of Miss Y. Endo is also acknowledged.

\section{References}

1) R. Brdicka, Collection Czechoslov. Chem. Communs., 5, 112, 148, 238 (1939).

2) R. Brdicka, Research, 1, 25 (1947).

3) G.J. Millar, Biochem. J., 53, 385, 393 (1953).

4) T. Hata and S. Matsushita, Mem. Research. Inst. Food Sci., Kyoto Univ., No. 7, 33 (1951).

5) M. Shinagawa, et al., "Advances in Polarography" I.S. Longmuir, ed., Pergamon Press, London, 1960, Vol. III, p. 1142.

6) V. Kalous, "Advances in Polarography” I.S. Longmuir, ed., Pergamon Press, London, 1960, Vol. III, p. 924.

7) M. Brezina "Advances in Polarography" I.S. Longmuir, ed., Pergamon Press, London, 1960, Vol. III, p. 933.

8) H. Sunahara, D.N. Ward and A.G. Griffin, J. Amer. Chem. Soc., 82, 6023 (1960).

9) I.M. Kolthoff, A. Anastasi and R.H. Tan, J. Amer. Chem. Soc., 80, 3235 (1958).

10) J. B. Willis, J·A. Friend, and R.P. Mellon, J. Amer. Chem. Soc., 67, 1680 (1945).

11) H.A. Laitinen and P. Kivalo, J. Amer. Chem. Soc., 75, 2198, 2865 (1953).

12) H.A. Laitinen, J.C. Bailar, Jr., H.F. Holts Claw and J.V. Quagliano, J. Amer. Chem. Sec., 70, 2999 (1948).

13) A.A. Vlcek, Collection Czechoslov. Chem. Communs., 20, 894 (1955).

14) N. Maki, Nature, 185, 682 (1960). 


\section{Brdicka 接触水素波に関寸る研究〔I \\ Brdicka 接触水素波に関するコバルトの睘元波}

砂原広志

-SH，-S-S-基を含むアミノ酸，ペプタイド，蛋白質 は塩化アンモニウムーアンモニヤ性コバルト塩溶液中 で 1 段又は 2 段の接触水素波を示すが，同時にコバル トの還元電位はいずれも正側電位に移行する，著者8 は先きにコバルト（III）の第 2 波の半波電位が，シスチ ンやオクタポリペプタイド等による正側電位の移行を 報告し，更に本論文において，蛋白質のもつ表面活性 作用をも考虑にいれて，一-S-基を有する Bovine Serum Albumine (B.S.A.) -S-S-基を含有しない Gelatin (ポーラログラフ的にコバルト馧中では接触 水素波をみとめないもの）及び合成非イオン性表面活 性物として，Tween 80, LEO をええび $0.1 M \mathrm{NH}_{4} \mathrm{Cl}$ $+0.1 M \mathrm{NH}_{3} \odot \operatorname{lm} M \mathrm{Co}\left(\mathrm{NH}_{3}\right)_{6} \mathrm{Cl}_{3}$ 溶液中に上記物 質を加えてコバルト第 1 , 第 2 波の挙動を観察した.

第 1 図A は, LEO, Tween 80 の添加によりコバル 卜第 2 波極大波高が減少し，同時にコバルト第 1 波の 半波電位の負荷電位への移行がみられ $-0.3 \mathrm{~V}$. 一 $0.4 \mathrm{~V}$. 附近に小さな prewave がみられた。第 1 図B においては, B.S.A.の添加によりコバルト第 2 波極大 波高の減少と同時にコバルト第 1 波の半波電位は負側 電位に移行し， $-0.1 \mathrm{~V}$. 附近に小さな prewave がみ

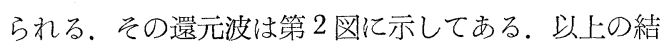
果により第 1 波の移行は前記 4 物質の表面活性作用に よるものであるが，コバルト第 2 波に対する挙動は異 なつている、その結果を第 3 図に示す。Tween 80, LEO による第 2 波の半波電位は負側電位に移動し, 同じ挙動が Gelatin 亿もみられるに反して，-S-S-基 を有する B.S.A. の場合コバルト第 2 波の半波電位は
正側に移行する．以上の結果より第 2 波極大波高が前 記 4 物質の添加により減少性を示すにもかかわらず， B.S.A. の場合のみは表面活性作用を有し更にそれ自 身の有している-S-S-基のコバルトイオンに対する錯 化作用の結果 $\mathrm{Co}\left(\mathrm{H}_{2} \mathrm{O}\right)_{6}{ }_{6}{ }^{2+}$ の還元波よりも正側儇元 電位をもつ B.S.A. とコバルトとの錯イオンの還元波 の生じるととが考兊られる. 又前記 4 物質の水銀滴え の吸着作用の差異は，それぞれの電気毛管曲線の測定 結果第 4 図にその結果が示してある. 図中Aはコバル 卜塩溶液のみの場合であり，B B B.S.A., C は Gelatin, D は LEO の添加の場合である. 特に B.S.A.の 場合, Gelatin とは異なる曲線を示している。乙れは B.S.A. のもつ水銀面光の吸着性に加光て更に-S-S-基 の作用によるものと推定される，前記したでとく蛋白 質及び表面活性剂によるコバルト第 1 波に対する影響 は，添加量の増加にしたがい小さな prewave が現わ れ主波が負側電位に移行し添加量が $1 \times 10^{-2} \%$ 以上に なると良好な波形を示す．蛋白質及び表面活性剤の添 加量によるコバルト第 1 波の主波の “ $\alpha \mathrm{n}$ ” の值を求め ると第 5 図に示したでとくなる。添加量 $1 \times 10^{-2} \%$ 以 上の増加に対して “ $\alpha \mathrm{n}$ ”の值が増加して1.0の值に近づ く傾向が共通性とみられる。乙の点関しては表面活 性剂の $\mathrm{Co}\left(\mathrm{NH}_{3}\right)_{6} 3+\mathrm{e} \rightarrow \mathrm{Co}\left(\mathrm{NH}_{3}\right)_{6} 2+$ の反応を示卞 コバルト第 1 波還元過程付する效響を示すものとし て興味あるが，その機構は復雑で明らかでなく本研究 においては B.S.A., Gelatin, Tween 80, LEO の第 1 波に対するやや類似的な挙動を報告した。 